\title{
Analisis Faktor - Faktor yang Mempengaruhi Penggunaan Informasi Akuntansi Pelaku UMKM
}

\author{
Alifiah Wulansari Mustofa ${ }^{1 *}$, Sri Trisnaningsih ${ }^{2 *}$ iD \\ ${ }^{12}$ Program Studi Akuntansi, Fakultas Ekonomi dan Bisnis, Universitas Pembangunan Nasional “Veteran” Jawa Timur, \\ Surabaya, Indonesia \\ *alfialifiahh@gmail.com
}

\begin{abstract}
Abstrak
Masalah permodalan yang sering dialami oleh UMKM dapat diatasi dengan adanya penggunaan informasi akuntansi, hal itu dapat digunakan sebagai modal dasar dalam mengambil keputusan yang berkaitan dengan pengembangan usaha. Tujuan dari penelitian ini adalah untuk mengetahui dan menganalisis pengaruh dari pengetahuan akuntansi, pengalaman usaha, pelatihan akuntansi dan skala usaha terhadap penggunaan informasi akuntansi. Penelitian ini menggunakan metode kuantitatif. Pelaku UMKM kedai kopi di Surabaya sebanyak 163 unit digunakan sebagai populasi, sedangkan sampel penelitian diambil dengan rumus slovin dan purposive sampling sebagai teknik pengambilan sampel sehingga diperoleh sampel sebanyak 62 unit. Data penelitian diperoleh secara langsung dengan cara menyebarkan kuesioner. Selanjutnya data dianalisis dengan regresi linear berganda melalui software IBM SPSS Statistics 22. Penelitian ini menunjukkan hasil bahwa 3 dari 4 variabel independen masing - masing berpengaruh positif terhadap penggunaan informasi akuntansi yang terdiri dari pengetahuan akuntansi, pelatihan akuntansi dan skala usaha. Sedangkan pengalaman usaha tidak berpengaruh positif terhadap penggunaan informasi akuntansi.
\end{abstract}

Kata Kunci: Pengetahuan Akuntansi, Pengalaman Usaha, Pelatihan Akuntansi, Skala Usaha, Penggunaan Informasi Akuntansi

\section{Abstract}

Capital problems that are often experienced by MSMEs can be overcome by the use of accounting information, it can be used as basic capital in making decisions related to business development. The purpose of this study is to determine and analyze the effect of accounting knowledge, business experience, accounting training and business scale on the use of accounting information. This research uses quantitative methods. As many as 163 units of MSMEs coffee shop in Surabaya were used as the population, while the research sample was taken using the Slovin formula and purposive sampling as the sampling technique so that a sample of 62 units was obtained. The research data were obtained directly by distributing questionnaires. Furthermore, the data were analyzed by multiple linear regression through IBM SPSS Statistics 22 software. This study shows that 3 out of 4 independent variables each have a positive effect on the use of accounting information consisting of accounting knowledge, accounting training and business scale. Meanwhile, business experience has no positive effect on the use of accounting information.

Keywords: Accounting Knowledge, Business Experience, Accounting Training, Business Scale, Use of Accounting Information

\section{Pendahuluan}

Tumbuhnya perekonomian negara Indonesia dipengaruhi oleh kegiatan ekonomi yang salah satunya adalah UMKM. Hal itu dikarenakan UMKM memiliki kontribusi positif seperti meningkatkan Produk Domestik Bruto dan lapangan pekerjaan, serta mengurangi kesenjangan tingkat kemiskinan. Selain itu, UMKM dinilai sebagai sektor yang selalu mampu menjadi penyelamat disaat adanya krisis ekonomi. Banyak usaha besar yang runtuh pada tahun 1998

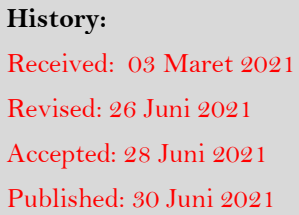


akibat krisis moneter, sedangkan UMKM tetap mampu bertahan dan menjadi penunjang perekonomian Indonesia hingga saat ini (Yolanda, Surya, \& Zarefar, 2020).

Besarnya pertumbuhan UMKM di Indonesia tidak terlepas dari permasalahan. Apabila permasalahan tersebut dapat diatasi, maka UMKM akan memberikan kontribusi yang semakin baik di setiap tahunnya. Terdapat beberapa masalah yang umum terjadi pada UMKM seperti kesulitan dalam mendapatkan modal, urusan perizinan, rendahnya kesadaran membayar pajak, kurangnya inovasi, dan tidak paham teknologi (Sandi, 2019). Dari beberapa permasalahan yang terjadi, permodalan menjadi salah satu permasalahan yang dihadapi oleh UMKM. Masalah permodalan yang dihadapi ialah kesulitan dalam memperoleh modal tambahan dari lembaga keuangan untuk pengembangan usaha. Untuk mengatasi hal tersebut, diperlukan laporan keuangan yang merupakan bentuk penyajian dari penggunaan informasi akuntansi. Ketika sedang menjalankan usaha dibutuhkan informasi akuntansi karena dapat dijadikan sebagai modal dasar untuk pengambilan keputusan, seperti keputusan pengembangan pasar dan harga, serta yang berkaitan dengan pemerintahan maupun kreditur (bank). Namun praktek dilapangan menunjukkan bahwa masih ada banyaknya UMKM yang tidak menggunakan informasi akuntansi (Yolanda, Surya, \& Zarefar, 2020). Menurut Priliandani, Pradnyanitasari, \& Kurniawan (2020) pelaku UMKM yang memiliki keterbatasan pengetahuan akuntansi dan beranggapan bahwa proses akuntansi rumit serta merasa tidak penting menggunakan laporan keuangan mengakibatkan pelaku UMKM yang tidak menggunakan informasi akuntansi menjadi banyak.

Informasi akuntansi akan dapat digunakan dengan baik apabila pelaku UMKM memiliki pengetahuan tentang akuntansi. Pelaku usaha akan mengalami kegagalan manajemen karena kesulitan dalam mengambil keputusan apabila pengetahuan akuntansi yang dimiliki rendah (Hudha, 2017). Pengetahuan akuntansi yang dimiliki pelaku usaha dipengaruhi oleh pengalaman pelaku usaha tersebut dalam menggunakan informasi akuntansi. Menurut Sukriani, Dewi, \& Wahyuni (2018) seseorang yang memiliki pengalaman luas akan lebih mudah berinteraksi dalam melaksanakan suatu pekerjaan. Pengalaman usaha yang dimiliki atau lamanya perusahaan dalam beroperasi mampu mengindikasikan kebutuhan penggunaan informasi akuntansi (Ariono \& Sugiyanto, 2018). Berkaitan dengan hal tersebut, penelitian dari Fithoriah \& Prananditya (2019) mendapatkan hasil bahwa penggunaan informasi akuntansi secara positif dipengaruhi oleh pengetahuan akuntansi dan pengalaman usaha. Selain itu dalam penggunaan informasi akuntansi dibutuhkan kemampuan dari pelaku usaha. Sehingga diperlukan pelatihan akuntansi sebagai bentuk usaha dalam meningkatkan dan mengembangkan kemampuan serta keterampilan dalam hal penggunaan informasi akuntansi untuk pengembangan usaha (Umami, Kaukab, \& Romandhon, 2020). Serta menurut Umami, Kaukab, \& Romandhon (2020) penggunaan informasi akuntansi dipengaruhi oleh besarnya skala usaha karena dengan besarnya skala usaha kebutuhan akuntansi akan meningkat sehingga bermanfaat untuk pengambilan keputusan. Penelitian dari Whetyningtyas (2016) mendapatkan hasil yang dapat membuktikan bahwa penggunaan informasi akuntansi secara signifikan dipengaruhi dengan pelatihan akuntansi dan skala usaha.

Kedai kopi dikategorikan sebagai UMKM non-pertanian dalam bidang usaha penyedia akomodasi dan penyedia makan minum. Jumlah UMKM terbanyak pada sektor perdagangan hotel dan restoran dalam hal penyedia akomodasi dan penyedia makan minum berada di Surabaya yaitu sebesar 169.980 unit (Dinas Koperasi dan UKM Provinsi Jawa Timur, 2020). Pada tiga tahun terakhir banyak pelaku UMKM yang melakukan inovasi produk dengan memulai usaha kedai kopi. Hal itu dibuktikan dengan adanya peningkatan kedai kopi di Indonesia pada tahun 2016 sampai akhir 2019, yaitu sebanyak 1.083 menjadi 3.000 unit (Prasetyo, 2020). Kota Surabaya menjadi salah satu kota yang terjadi peningkatan kedai kopi tersebut. Menurut Head of Marketing dari PT Toffin Indonesia yaitu Ario Fajar mengatakan 
bisnis kopi sangat bagus dan pada tahun 2020 diperkirakan terjadi peningkatan sekitar 15\% sampai 20\% (Prasetyo, 2020). Dengan adanya jumlah kedai kopi yang semakin meningkat di setiap tahunnya, diharapkan setiap kedai kopi mampu mengembangkan usahanya agar lebih unggul dari pesaingnya. Untuk itu diperlukan penggunaan informasi akuntansi sebagai modal dasar dalam pengambilan keputusan yang tepat dalam hal keuangan maupun non keuangan.

Tabel 1. Persentase Penggunaan Laporan Keuangan pada Kedai Kopi di Surabaya

\begin{tabular}{|c|c|c|c|}
\hline No. & Deskripsi & Jumlah & Persentase \\
\hline 1. & Menggunakan Laporan Keuangan & 11 & $23,9 \%$ \\
\hline 2. & Tidak Menggunakan Laporan Keuangan & 35 & $76,7 \%$ \\
\hline & Total & 46 & $100 \%$ \\
\hline
\end{tabular}

Sumber: Data diolah, 2020

Berkaitan dengan tabel 1 menunjukkan masih banyak pelaku UMKM kedai kopi yang tidak menggunakan informasi akuntansi. Pelaku UMKM kedai kopi di Surabaya yang tidak melakukan pencatatan laporan keuangan hanya menggunakan pencatatan penjualan dan pengeluaran kas, atau memiliki laporan keuangan yang hampir lengkap tapi tidak rapi. Dari adanya penelitian ini, diharapkan UMKM tersebut dapat tumbuh dengan kualitas yang baik terutama dalam penggunaan informasi akuntansi agar bermanfaat untuk pengambilan keputusan terkait strategi bisnis agar tidak mengalami kegagalan usaha.

Uraian diatas menunjukkan adanya rumusan masalah berikut: 1. Apakah pengetahuan akuntansi pelaku UMKM berpengaruh terhadap penggunaan informasi akuntansi; 2. Apakah pengalaman usaha pelaku UMKM berpengaruh terhadap penggunaan informasi akuntansi?; 3. Apakah pelatihan akuntansi berpengaruh terhadap penggunaan informasi akuntansi?; 4. Apakah skala usaha berpengaruh terhadap penggunaan informasi akuntansi?. Penelitian ini memiliki tujuan yaitu untuk mengetahui dan menganalisis pengaruh masing - masing dari pengetahuan akuntansi, pengalaman usaha, pelatihan akuntansi dan skala usaha terhadap penggunaan informasi akuntansi.

An Accounting Concept of Revenue adalah disertasi dari George J. Staubus yang mengemukakan teori mengenai kegunaan keputusan ditahun 1954. Menurut Scott (2009:59) pendekatan kegunaan keputusan atas informasi akuntansi ini merupakan suatu pendekatan dengan basis biaya historis pada laporan keuangan. Hal - hal yang ditekankan dalam pendekatan ini seperti pengguna laporan keuangan, informasi yang dibutuhkan, keputusan yang diambil, dan kemampuan dalam menggunakan informasi akuntansi.

UMKM di Indonesia memiliki pengertian dan kriteria yang dapat dilihat di Undang Undang Nomor 20 Tahun 2008 Pasal 1 tentang Usaha Mikro, Kecil dan Menengah. Jumlah kepemilikan kekayaan bersih dari usaha mikro tidak melebihi Rp 50 juta, serta penjualan memiliki hasil yang tidak melebihi Rp 300 juta. Selain itu jumlah kepemilikan kekayaan bersih dari usaha kecil berada diantara Rp 50 juta s.d. Rp 500 juta, serta penjualan memiliki hasil yang berada diantara Rp 300 juta s.d. Rp 2,5 miliar. Serta jumlah kepemilikan kekayaan bersih dari usaha menengah berada diantara Rp 500 juta s.d. Rp 10 miliar, dan penjualan memiliki hasil yang berada diantara $\mathrm{Rp} 2,5$ miliar s.d. Rp 50 miliar.

Suatu entitas mempunyai posisi keuangan dan kinerja keuangan yang diharuskan untuk disajikan secara terstruktur dalam bentuk laporan keuangan (Ikatan Akuntan Indonesia, 2009:5). Beberapa bentuk laporan keuangan yang diungkapkan dalam SAK ETAP terdiri dari neraca, laporan laba rugi, laporan perubahan ekuitas, dan laporan arus kas serta catatan atas laporan keuangan. Investor dan kreditor lainnya membutuhkan informasi keuangan dari suatu entitas untuk membuat keputusan, sehingga dalam hal ini diperlukan adanya laporan keuangan (Kieso, Weygandt, \& Warfield, 2018). 
Menurut Sitorus (2017) akuntansi diartikan sebagai suatu cara untuk memproses data keuangan yang dilakukan dalam perusahaan apabila dilihat dari kegiatannya. Sedangkan apabila dilihat dari pemakaiannya, akuntansi diartikan sebagai suatu disiplin yang memiliki efisiensi dalam menjalankan dan mengevaluasi berbagai aktivitas atas informasi yang dihasilkan. Menurut Priliandani, Pradnyanitasari, \& Kurniawan (2020) keputusan ekonomi yang diambil sangat dipengaruhi oleh informasi akuntansi karena informasi akuntansi berisi informasi kuantitatif yang berasal dari suatu entitas ekonomi. Dalam hal ini penggunaan informasi akuntansi memiliki arti sebagai cara untuk menggunakan informasi akuntansi yang memiliki manfaat dalam pengambilan keputusan bisnis. Hendrawati (2017) mengklasifikasikan informasi akuntansi menjadi statutory accounting information dan budgetary information serta additional accounting information.

Menurut Tambunan (2019) akuntansi didefinisikan sebagai suatu cara untuk memproses data keuangan dalam suatu perusahaan. Sedangkan pengetahuan akuntansi diartikan sebagai seperangkat ilmu yang dimiliki oleh pelaku usaha mengenai cara untuk memproses data keuangan organisasi yang memiliki manfaat untuk mengambil keputusan. Menurut Hendrawati (2017) pengetahuan akuntansi yang diperoleh berdasarkan suatu konsep dan fakta disebut sebagai pengetahuan deklaratif, sedangkan pengetahuan akuntansi yang menyesuaikan dengan aturan yang berlaku disebut sebagai pengetahuan prosedural. Pengetahuan akuntansi yang dimiliki dapat tercermin dari perilaku pelaku usaha dalam mengelola keuangan perusahaan. Berkaitan dengan hal tersebut maka informasi akuntansi yang digunakan sangat dipengaruhi pengetahuan akuntansi pelaku UMKM.

Pengalaman usaha merupakan suatu proses yang dapat membentuk pengetahuan serta keterampilan akibat adanya keterlibatan karyawan didalamnya (Fithoriah \& Prananditya, 2019). Lamanya seseorang dalam berkarya untuk menerapkan keahliannya di masyarakat dapat dilihat dari pengalaman yang dimiliki (Trisnaningsih \& Haryadi, 2009). Apabila kompleksitas usaha meningkat dan persaingan semakin ketat, pelaku UMKM akan semakin membutuhkan pengalaman usaha dalam menjalankan suatu usaha. Menurut Tambunan (2019) dengan adanya pengalaman usaha maka pelaku UMKM akan mengetahui pemecahan masalah atas berbagai kendala yang dihadapi.

Pelatihan akuntansi menjadi salah satu faktor yang berperan saat menjalankan usaha. Hal itu dikarenakan pelatihan akuntansi dapat menentukan seberapa baik kemampuan seorang pelaku UMKM dalam menguasai akuntansi. Whetyningtyas (2016) menganggap bahwa pelaku UMKM akan menggunakan informasi akuntansi apabila telah mengikuti pelatihan akuntansi, sehingga pelaku UMKM tersebut dapat melakukan pengambilan keputusan agar mampu menjalankan usaha dengan baik. Pelatihan akuntansi dalam hal ini adalah pelatihan yang dilakukan selain dari lembaga pendidikan sekolah atau perguruan tinggi, seperti balai pelatihan departemen ataupun dinas (Rikah, 2018).

Skala usaha diartikan sebagai kemampuan perusahaan untuk mengelola suatu usaha yang dijalankan dengan melihat besarnya aset, jumlah karyawan serta pendapatan pada suatu periode (Kurniawan, Mahsuni, \& Hariri, 2020). Besarnya pendapatan menunjukkan adanya perputaran aset atau modal dari suatu usaha, sehingga apabila pendapatan yang didapatkan semakin besar maka kompleksitas usaha dalam menggunakan informasi akuntansi akan semakin besar. Sedangkan menurut Nirwana \& Purnama (2019) jumlah karyawan yang ada mampu menunjukkan kemampuan perusahaan dalam mengoperasionalkan usaha yang dijalankan, sehingga apabila karyawan memiliki jumlah yang semakin besar, kompleksitas usaha akan semakin besar dan semakin dibutuhkan penggunaan informasi akuntansi dalam suatu usaha.

Hipotesis dalam penelitian ini adalah $\mathrm{H}_{1}$ : Pengetahuan akuntansi berpengaruh positif terhadap penggunaan informasi akuntansi. $\mathrm{H}_{2}$ : Pengalaman usaha berpengaruh positif terhadap penggunaan informasi akuntansi. $\mathrm{H}_{3}$ : Pelatihan akuntansi berpengaruh positif terhadap 
penggunaan informasi akuntansi. $\mathrm{H}_{4}$ : Skala usaha berpengaruh positif terhadap penggunaan informasi akuntansi.

\section{Metode}

Kuantitatif merupakan jenis metode yang digunakan untuk penelitian ini. Variabel independen terdiri atas pengetahuan akuntansi (X1), pengalaman usaha (X2), pelatihan akuntansi (X3), dan skala usaha (X4). Sedangkan variabel dependen yaitu penggunaan informasi akuntansi (Y). Variabel penelitian diukur dengan skala likert yang berupa lima alternatif jawaban. Adapun jawaban tersebut diberi skor yang berupa angka 1 sampai 5.

Populasi pada penelitian ini yaitu pelaku UMKM kedai kopi di Surabaya sebanyak 163 unit. Besaran sampel dihitung melalui rumus slovin dengan toleransi ketidaktelitian (e) sebanyak $10 \%$. Sampel diambil dengan menggunakan purposive sampling yaitu ditentukan berdasarkan kriteria. Sehingga sampel penelitian sebanyak 62 unit UMKM kedai kopi di Surabaya yang sesuai dengan kriteria. Data penelitian didapatkan dari data primer yang diperoleh secara langsung dari responden yang dijadikan sampel, yaitu pelaku UMKM kedai kopi di Surabaya. Teknik pengumpulan data penelitian dilakukan melalui penyebaran kuesioner secara offline dan online dengan google formulir.

Kuesioner penelitian diuji dengan uji validitas dan uji reliabilitas. Kemudian dilakukan uji asumsi klasik agar kualitas data dapat teruji. Regresi linear berganda digunakan sebagai teknik analisis data dan dilakukan dengan software IBM SPSS Statistics 22. Berikut adalah persamaan dari regresi linear berganda:

$Y=a+b 1 X 1+b 2 X 2+b 3 X 3+b 4 X 4+e$

Keterangan:

$Y=$ Penggunaan Informasi Akuntansi

$a=$ Konstanta

$b=$ Koefisien regresi linear berganda

$X 1=$ Pengetahuan akuntansi

$X 2=$ Pengalaman usaha

$X 3=$ Pelatihan akuntansi

$X 4=$ Skala usaha

$e=$ Faktor lain yang mempengaruhi variabel dependen

\section{Hasil dan Pembahasan}

Pengambilan data dilaksanakan dari 26 Januari 2021 sampai 5 Februari 2021 dengan menyebarkan kuesioner kepada 90 responden, namun terdapat 28 responden yang tidak mengembalikan kuesioner. Kuesioner yang kembali berasal dari 62 responden telah memenuhi jumlah sampel dan kriteria yang dibutuhkan, sehingga layak digunakan. Karakteristik responden pada UMKM kedai kopi di Surabaya dalam penelitian ini mayoritas laki - laki sebanyak 55 orang dan 7 orang responden perempuan.

Uji validitas dengan korelasi bivariate menunjukkan nilai $r$ hitung yang dihasilkan melebihi nilai $\mathrm{r}$ tabel (0,2500). Menurut Ghozali (2018:52) validnya suatu pertanyaan dalam kuesioner memiliki nilai $r$ hitung yang melebihi $r$ tabel. Sedangkan hasil uji reliabilitas menunjukkan nilai Cronbach's Alpha yang melebihi 0,6 sehingga kuesioner penelitian memiliki 
variabel yang reliabel dan layak digunakan menjadi suatu alat untuk mengukur instrumen kuesioner.

Kolmogorov-Smirnov adalah bentuk pengujian yang dilakukan pada penelitian ini untuk uji normalitas, sehingga dalam hal ini data akan dinyatakan berdistribusi normal apabila nilai signifikansi yang dihasilkan melebihi 0,05 dan sebaliknya (Ghozali, 2018:166). Hasil uji normalitas dengan IBM SPSS Statistics 22 pada tabel 2 menunjukkan nilai signifikansi sebesar 0,200 . Hal ini memiliki arti bahwa data yang diperoleh dinyatakan berdistribusi normal karena nilai signifikansi yang dihasilkan melebihi 0,05 .

Tabel 2. Hasil Uji Normalitas

One-Sample Kolmogorov-Smirnov Test

\begin{tabular}{llr}
\hline & & Unstandardized Residual \\
\hline $\mathrm{N}$ & & 62 \\
Normal Parameters & $\mathrm{a}, \mathrm{b}$ &, 0000000 \\
& Mean & 5,39678227 \\
Most Extreme Differences & Std. Deviation &, 066 \\
& Absolute &, 063 \\
& Positive &,- 066 \\
Test Statistic & Negative &, 066 \\
Asymp. Sig. (2-tailed) & &, $200^{\mathrm{c}, \mathrm{d}}$ \\
\hline
\end{tabular}

Sumber: Output IBM SPSS Statistics 22, 2021

Uji multikolinieritas dalam model regresi memiliki hasil seperti yang ditampilkan pada tabel 3, yang mana apabila nilai tolerance tidak melebihi 0,10 atau nilai VIF melebihi 10 maka terdapat multikolinieritas dan sebaliknya.

Tabel 3. Hasil Uji Multikolinieritas

\begin{tabular}{|c|c|c|c|}
\hline \multirow{2}{*}{ Variabel Independen } & \multicolumn{2}{|c|}{ Coliniearity Statistic } & \multirow{2}{*}{ Keterangan } \\
\hline & Tolerance & VIF & \\
\hline Pengetahuan Akuntansi & 0,435 & 2,297 & \multirow{4}{*}{ Bebas dari multikolinieritas } \\
\hline Pengalaman Usaha & 0,347 & 2,882 & \\
\hline Pelatihan Akuntansi & 0,508 & 1,970 & \\
\hline Skala Usaha & 0,412 & 2,429 & \\
\hline
\end{tabular}

Sumber: Data diolah, 2021

Uji heteroskedastisitas memiliki hasil yang ditampilkan pada tabel 4, pengujian ini dilakukan dengan uji gletser yang mana apabila probabilitas signifikansinya melebihi 0,05 maka model regresi akan dinyatakan tidak ada heteroskedastisitas dan sebaliknya.

Tabel 4. Hasil Uji Heteroskedastisitas

\begin{tabular}{lcc}
\hline \multicolumn{1}{c}{ Variabel Independen } & Nilai Sig. & Keterangan \\
\hline Pengetahuan Akuntansi & 0,416 & \\
\cline { 1 - 2 } Pengalaman Usaha & 0,745 & Tidak ada heteroskedastisitas \\
\hline Pelatihan Akuntansi & 0,512 & \\
\hline Skala Usaha & 0,326 & \\
\hline Sunn & &
\end{tabular}

Sumber: Data diolah, 2021

Uji ketepatan model (Uji F) dimaksudkan agar dapat mengetahui apakah variabel independen seluruhnya mampu mempengaruhi variabel dependen sehingga formulasi dari model persamaan regresi linear berganda dinyatakan sudah tepat. Hasil analisis data pada tabel 5 menunjukkan nilai signifikansi tidak melebihi 0,05 dan nilai $\mathrm{F}$ hitung melebihi $\mathrm{F}$ tabel $(2,76)$. Dari pengujian ini dinyatakan bahwa variabel independen seluruhnya mampu mempengaruhi 
variabel dependen, serta formulasi dari model persamaan regresi linear berganda dinyatakan sudah tepat.

Tabel 5. Hasil Uji F

ANOVA $^{\mathrm{a}}$

\begin{tabular}{llrrrrr}
\hline Model & Sum of Squares & df & Mean Square & F & \multicolumn{1}{c}{ Sig. } \\
\hline \multirow{2}{*}{1} & 3477,230 & 4 & 869,308 & 27,890 &, $000^{\mathrm{b}}$ \\
\cline { 2 - 7 } & Regression & 1776,641 & 57 & 31,169 & & \\
\cline { 2 - 6 } & Residual & 5253,871 & 61 & & & \\
\hline
\end{tabular}

Sumber: Output IBM SPSS Statistics 22, 2021

Uji t dilakukan agar mampu mengetahui sejauh apa variabel dependen dipengaruhi secara individual oleh variabel independen. Dalam uji t terdapat hipotesis statistik yang hendak diuji, yaitu $\mathrm{H}_{0}$ (hipotesis nol) dan $\mathrm{H}_{\mathrm{A}}$ (hipotesis alternatif). Hasil uji t ditampilkan pada tabel 6 dengan melihat besaran nilai $t$ dan nilai signifikansi. Nilai t tabel untuk alpha 0,05 diperoleh sebesar 2,00172 .

Tabel 6. Hasil Uji t

Coefficients $^{\mathrm{a}}$

\begin{tabular}{|c|c|c|c|c|c|c|}
\hline & & \multicolumn{2}{|c|}{$\begin{array}{c}\text { Unstandardized } \\
\text { Coefficients }\end{array}$} & \multirow{2}{*}{$\begin{array}{c}\text { Standardized } \\
\text { Coefficients }\end{array}$} & \multirow[b]{2}{*}{$\mathrm{t}$} & \multirow[b]{2}{*}{ Sig. } \\
\hline \multicolumn{2}{|c|}{ Model } & B & Std. Error & & & \\
\hline \multirow[t]{5}{*}{1} & (Constant) & 8,204 & 4,205 & & 1,951 &, 056 \\
\hline & Pengetahuan Akuntansi (X1) & ,635 & ,267 & ,278 & 2,381 &, 021 \\
\hline & Pengalaman Usaha (X2) & ,348 & ,420 & 108 &, 827 &, 412 \\
\hline & Pelatihan Akuntansi (X3) & 601 & 279 & 232 & 2,150 &, 036 \\
\hline & Skala Usaha (X4) & ,564 & ,204 & ,332 & 2,768 &, 008 \\
\hline
\end{tabular}

Sumber: Output IBM SPSS Statistics 22, 2021

Variabel pengetahuan akuntansi (X1) memiliki nilai signifikansi yang tidak melebihi 0,05 serta memiliki nilai $\mathrm{t}$ hitung yang melebihi t tabel. Berkaitan dengan hal tersebut maka $\mathrm{H}_{0}$ ditolak dan $\mathrm{H}_{1}$ diterima, sehingga dinyatakan terdapat pengaruh positif yang signifikan secara individual pengetahuan akuntansi (X1) terhadap penggunaan informasi akuntansi (Y).

Variabel pengalaman usaha (X2) memiliki nilai signifikansi melebihi 0,05 serta memiliki nilai t hitung tidak melebihi t tabel. Berkaitan dengan hal tersebut maka $\mathrm{H}_{0}$ diterima dan $\mathrm{H}_{2}$ ditolak, sehingga dinyatakan tidak terdapat pengaruh positif yang signifikan secara individual pengalaman usaha (X2) terhadap penggunaan informasi akuntansi (Y).

Variabel pelatihan akuntansi (X3) memiliki nilai signifikansi tidak melebihi 0,05 serta memiliki nilai t hitung melebihi $\mathrm{t}$ tabel. Berkaitan dengan hal tersebut maka $\mathrm{H}_{0}$ ditolak dan $\mathrm{H}_{3}$ diterima, sehingga dinyatakan terdapat pengaruh positif yang signifikan secara individual pelatihan akuntansi (X3) terhadap penggunaan informasi akuntansi (Y).

Variabel skala usaha (X4) memiliki nilai signifikansi tidak melebihi 0,05 serta memiliki nilai t hitung melebihi t tabel. Berkaitan dengan hal tersebut maka $\mathrm{H}_{0}$ ditolak dan $\mathrm{H}_{4}$ diterima, sehingga dinyatakan terdapat pengaruh positif yang signifikan secara individual skala usaha (X4) terhadap penggunaan informasi akuntansi (Y).

Koefisien determinasi $\left(\mathrm{R}^{2}\right)$ dimaksudkan agar mampu mengukur variasi variabel dependen sehingga dapat dinyatakan dalam model regresi. Pengujian koefisien determinasi $\left(\mathrm{R}^{2}\right)$ yang ditampilkan pada tabel 7 memperoleh $\mathrm{R}$ Square senilai 0,662 dalam persentase $66,2 \%$. Hal ini dapat diartikan bahwa variabel dependen (penggunaan informasi akuntansi) dipengaruhi oleh variabel independen (pengetahuan akuntansi, pengalaman usaha, pelatihan akuntansi dan skala 
usaha) senilai persentase $66,2 \%$. Dan sisanya senilai persentase $33,8 \%$ dipengaruhi oleh variabel lain diluar model regresi.

Tabel 7. Hasil Uji Koefisien Determinasi $\left(\mathrm{R}^{2}\right)$

\section{Model Summary}

\begin{tabular}{lrrrr}
\hline Model & R & R Square & Adjusted R Square & Std. Error of the Estimate \\
\hline 1 &, $814^{\mathrm{a}}$ &, 662 &, 638 & 5,583 \\
\hline
\end{tabular}

Sumber: Output IBM SPSS Statistics 22, 2021

\section{Pengaruh Pengetahuan Akuntansi terhadap Penggunaan Informasi Akuntansi}

Nilai koefisien yang dihasilkan variabel pengetahuan akuntansi (X1) sebesar 0,635. Hal itu menunjukkan bahwa penggunaan informasi akuntansi akan meningkat seiring dengan kenaikan pengetahuan akuntansi. Sedangkan pada uji t memperoleh hasil nilai signifikansi sebesar 0,021 dan nilai t sebesar 2,381. Berkaitan dengan hal tersebut maka hipotesis pertama $\left(\mathrm{H}_{1}\right)$ diterima.

Kepemilikan pengetahuan akuntansi dari pelaku UMKM merupakan salah satu faktor dalam penggunaan informasi akuntansi. Dari hasil jawaban kuesioner, diperoleh bahwa pelaku UMKM kedai kopi di Surabaya memiliki pengetahuan akuntansi yang baik. Namun masih banyak dari mereka yang ragu - ragu dalam menerapkan pencatatan akuntansi yang sesuai dengan ketentuan akuntansi dalam menjalankan usaha. Penelitian ini mendapatkan hasil yang sesuai dengan Khairunnisa \& Rustiana (2019) yang menyebutkan bahwa pengetahuan akuntansi berpengaruh positif signifikan terhadap penggunaan informasi akuntansi. Serta sesuai dengan penelitian Priliandani, Pradnyanitasari, \& Kurniawan (2020) dan Umami, Kaukab, \& Romandhon (2020) yang menunjukkan bahwa penggunaan informasi akuntansi secara positif dipengaruhi oleh pengetahuan akuntansi.

\section{Pengaruh Pengalaman Usaha terhadap Penggunaan Informasi Akuntansi}

Nilai koefisien yang dihasilkan variabel pengalaman usaha (X2) sebesar 0,348. Hal itu menunjukkan bahwa penggunaan informasi akuntansi akan meningkat seiring dengan kenaikan pengalaman usaha. Sedangkan pada uji t memperoleh hasil nilai signifikansi sebesar 0,412 dan nilai $\mathrm{t}$ sebesar 0,827. Berkaitan dengan hal tersebut maka hipotesis kedua $\left(\mathrm{H}_{2}\right)$ ditolak.

Pengalaman usaha yang dimiliki tidak mempengaruhi pelaku UMKM dalam menggunakan informasi akuntansi. Pada hasil jawaban kuesioner, diperoleh bahwa pelaku UMKM kedai kopi di Surabaya mengetahui bahwa pengalaman usaha yang dimiliki dapat meningkatkan kemajuan usaha. Namun mereka menyadari bahwa pengalaman usaha yang dimiliki belum cukup sehingga mereka belum mampu menyelesaikan permasalahan atas kendala yang dihadapi. Penelitian ini memperoleh hasil yang sesuai dengan Tambunan (2019) yang menyatakan bahwa penggunaan informasi akuntansi tidak dipengaruhi oleh pengalaman usaha. Namun hasil penelitian ini tidak sesuai dengan penelitian Fithoriah \& Prananditya (2019) yang menyebutkan bahwa penggunaan informasi akuntansi dipengaruhi secara positif signifikan oleh pengalaman usaha.

\section{Pengaruh Pelatihan Akuntansi terhadap Penggunaan Informasi Akuntansi}

Nilai koefisien yang dihasilkan variabel pelatihan akuntansi (X3) sebesar 0,601. Hal itu menunjukkan bahwa penggunaan informasi akuntansi akan meningkat seiring dengan kenaikan pelatihan akuntansi. Sedangkan pada uji t memperoleh hasil nilai signifikansi sebesar 0,036 dan nilai $\mathrm{t}$ sebesar 2,150. Berkaitan dengan hal tersebut maka hipotesis ketiga $\left(\mathrm{H}_{3}\right)$ diterima.

Salah satu faktor pelaku UMKM dalam menggunakan informasi akuntansi didorong dari adanya pelatihan akuntansi. Dari hasil jawaban kuesioner, diperoleh bahwa pelaku UMKM kedai kopi di Surabaya memerlukan pelatihan akuntansi dan bersedia mengikuti pelatihan tersebut apabila diadakan. Hal itu dikarenakan dengan mengikuti pelatihan akuntansi, pelaku UMKM kedai kopi di Surabaya dapat meningkatkan pengetahuan dan dapat memperbaiki 
kinerja usaha yang sedang dijalankan khususnya yang berkaitan dengan penggunaan informasi akuntansi. Penelitian ini memperoleh hasil yang sesuai dengan Novianti, Mustika, \& Eka (2018) yang menunjukkan bahwa pelatihan akuntansi berpengaruh positif terhadap penggunaan informasi akuntansi pada pelaku UMKM. Serta sesuai dengan penelitian Hadi, Putri, \& Faturokhman (2019) dan Efriyenty (2020) yang menunjukkan bahwa penggunaan informasi akuntansi pada UMKM dipengaruhi secara positif oleh pelatihan akuntansi.

\section{Pengaruh Skala Usaha terhadap Penggunaan Informasi Akuntansi}

Nilai koefisien yang dihasilkan variabel skala usaha (X4) sebesar 0,564. Hal itu menunjukkan bahwa penggunaan informasi akuntansi akan meningkat seiring dengan kenaikan skala usaha. Sedangkan pada uji t memperoleh hasil nilai signifikansi sebesar 0,008 dan nilai $\mathrm{t}$ sebesar 2,768. Berkaitan dengan hal tersebut maka hipotesis keempat $\left(\mathrm{H}_{4}\right)$ diterima.

Salah satu faktor pelaku UMKM dalam menggunakan informasi akuntansi didorong dari adanya skala usaha. Dari hasil jawaban kuesioner, diperoleh bahwa pelaku UMKM kedai kopi di Surabaya mampu menggunakan informasi akuntansi dalam menjalankan usaha. Pelaku UMKM kedai kopi di Surabaya telah menggunakan informasi akuntansi tersebut sebagai dasar pengambilan keputusan dalam mempertimbangkan bagaimana pendapatan yang diperoleh dapat membiayai operasional usaha serta karyawan yang dipekerjakan. Selain itu pendapatan yang didapatkan dari kegiatan usaha dalam satu periode akuntansi mampu menunjukkan adanya perputaran aset dan modal yang dimiliki oleh UMKM kedai kopi di Surabaya. Dalam hal ini apabila semakin besar pendapatan yang didapatkan maka kompleksitas usaha dalam menggunakan informasi akuntansi semakin besar. Penelitian ini memperoleh hasil yang sesuai dengan Whetyningtyas (2016) dan Yasa, Herawati, \& Sulindawati (2017) serta Zulkarnnaeni \& Rizki (2019) yang menunjukkan bahwa penggunaan informasi akuntansi secara signifikan dipengaruhi oleh skala usaha.

\section{Simpulan dan Saran}

Kesimpulan yang didapatkan dari hasil dan pembahasan yang sebelumnya telah diuraikan yaitu pengetahuan akuntansi (X1) berpengaruh positif terhadap penggunaan informasi akuntansi (Y). Pengalaman usaha (X2) tidak berpengaruh positif terhadap penggunaan informasi akuntansi (Y). Dan pelatihan akuntansi (X3) berpengaruh positif terhadap penggunaan informasi akuntansi (Y). Serta skala usaha (X4) berpengaruh positif terhadap penggunaan informasi akuntansi (Y). Sehingga dalam hal ini seluruh hipotesis diterima, kecuali hipotesis kedua $\left(\mathrm{H}_{2}\right)$.

Saran yang dapat diberikan kepada pihak terkait dan peneliti selanjutnya yaitu diharapkan bagi pelaku UMKM kedai kopi di Surabaya untuk menggunakan informasi akuntansi secara konsisten, sehingga dapat membantu proses pengambilan keputusan terkait dengan pengembangan usaha yang dijalankan agar lebih unggul dari pesaingnya. Dan diharapkan kepada peneliti selanjutnya untuk menambahkan beberapa variabel lain diluar dari pembahasan ini, sehingga dapat menambah variasi topik penelitian. Serta diharapkan untuk memperluas jumlah sampel atau mengganti bidang UMKM lain agar hasil penelitian dapat merepresentasikan pengaruh dari tiap variabel.

\section{Daftar Pustaka}

Ariono, I., \& Sugiyanto, B. (2018). Analisis Faktor-Faktor yang Mempengaruhi Persepsi Atas Informasi Akuntansi Keuangan Serta Keberhasilan dalam Mengelola Perusahaan Kecil dan Menengah (Studi Empiris Pada UMKM Industri Makanan di Wonosobo). Journal of Economic, Management, Accounting and Technology (JEMATech), 1(1), 91-104. https://doi.org/10.32500/jematech.v1i1.215 
Dinas Koperasi dan UKM Provinsi Jawa Timur. (2020). Data UKM. Retrieved December 16, 2020, from Dinas Koperasi dan UKM Provinsi Jawa Timur website: http://diskopukm.jatimprov.go.id/info/data-ukm

Efriyenty, D. (2020). Analisis Faktor-Faktor Yang Mempengaruhi Penggunaan Informasi Akuntansi Pada UMKM Kota Batam. Jurnal Bisnis Terapan, 04(01), 69-82. https://doi.org/10.24123/jbt.v4i1.2814

Fithoriah, S., \& Prananditya, A. (2019). Pengaruh Tingkat Pendidikan, Pengetahuan Akuntansi, Pengalaman Usaha dan Skala Usaha terhadap Penggunaan Informasi Akuntansi Pada Usaha Kecil Menengah (Studi Kasus Pada pelaku UKM di Jalan Karangjati dan Jalan Pringapus Kabupaten Semarang). Jurnal Ilmiah Mahasiswa S1 Akuntansi Universitas Pandanaran, 5(5).

Ghozali, I. (2018). Aplikasi Analisis Multivariate dengan Program IBM SPSS 25 (9th ed.). Semarang: Badan Penerbit Universitas Diponegoro.

Hadi, A. P., Putri, N. K., \& Faturokhman, A. (2019). Faktor-Faktor Yang Mempengaruhi Penggunaan Informasi Akuntansi Pada Usaha Kecil Dan Menengah. Jurnal Akuntansi Dan Keuangan, 16(2), 165-171.

Hendrawati, E. (2017). Analisis Faktor-Faktor Yang Mempengaruhi Penggunaan Informasi Akuntansi Pada Usaha Mikro, Kecil dan Menengah (UMKM). Jurnal Ilmu Manajemen, 1(2), 43-66.

Hudha, C. (2017). Pengaruh Tingkat Pendidikan, Pengetahuan Akuntansi Dan Pelatihan Akuntansi Terhadap Penggunaan Informasi Akuntansi Dimoderasi Ketidakpastian Lingkungan Usaha Kecil Menengah. Jurnal Ekonomi Pendidikan Dan Kewirausahaan, Vol. 5, pp. 68-90. https://doi.org/10.26740/jepk.v5n1.p68-90

Ikatan Akuntan Indonesia. (2009). Standar Akuntansi Keuangan Entitas Tanpa Akuntabilitas Publik. Jakarta.

Khairunnisa, \& Rustiana, S. (2019). The Effect of Education Level, Business Age and Accounting Knowledge on The Implementation of SME Accounting Information Systems in Industrial Era 4.0 (Empirical Study of MSME in South Tangerang). International Conference on Economics, Management, and Accounting Conference, KnE Social Sciences, 872-887. https://doi.org/10.18502/kss.v3i26.5420

Kurniawan, M. A., Mahsuni, A. W., \& Hariri. (2020). Analisis Faktor-Faktor Yang Mempengaruhi Penggunaan Informasi Akuntansi Pada Usaha UMKM (Studi Empiris Pada UMKM di Kota Malang). E-Jra, 09(02), 132-145.

Nirwana, A., \& Purnama, D. (2019). Pengaruh Jenjang Pendidikan, Skala Usaha Dan Lama Usaha Terhadap Penggunaan Informasi Akuntansi Pada UMKM Di Kecamatan Ciawigebang. Jurnal Riset Keuangan Dan Akuntansi, 5(4), 55-65. https://doi.org/10.25134/jrka.v5i1.1881

Novianti, D., Mustika, I. W., \& Eka, L. H. (2018). Pengaruh Tingkat Pendidikan, Pelatihan Akuntansi, Umur Usaha Dan Skala Usaha Pelaku UMKM Terhadap Penggunaan Informasi Akuntansi Di Kecamatan Purwokerto Utara. Jurnal Ekonomi, Bisnis, Dan Akuntansi (JEBA), 20(3), 1-14.

Ariono, I., \& Sugiyanto, B. (2018). Analisis Faktor-Faktor yang Mempengaruhi Persepsi Atas Informasi Akuntansi Keuangan Serta Keberhasilan dalam Mengelola Perusahaan Kecil dan 
Menengah (Studi Empiris Pada UMKM Industri Makanan di Wonosobo). Journal of Economic, Management, Accounting and Technology (JEMATech), 1(1), 91-104. https://doi.org/10.32500/jematech.v1i1.215

Dinas Koperasi dan UKM Provinsi Jawa Timur. (2020). Data UKM. Retrieved December 16, 2020, from Dinas Koperasi dan UKM Provinsi Jawa Timur website: http://diskopukm.jatimprov.go.id/info/data-ukm

Efriyenty, D. (2020). Analisis Faktor-Faktor Yang Mempengaruhi Penggunaan Informasi Akuntansi Pada UMKM Kota Batam. Jurnal Bisnis Terapan, 04(01), 69-82. https://doi.org/10.24123/jbt.v4i1.2814

Fithoriah, S., \& Prananditya, A. (2019). Pengaruh Tingkat Pendidikan, Pengetahuan Akuntansi, Pengalaman Usaha dan Skala Usaha terhadap Penggunaan Informasi Akuntansi Pada Usaha Kecil Menengah (Studi Kasus Pada pelaku UKM di Jalan Karangjati dan Jalan Pringapus Kabupaten Semarang). Jurnal Ilmiah Mahasiswa S1 Akuntansi Universitas Pandanaran, 5(5).

Ghozali, I. (2018). Aplikasi Analisis Multivariate dengan Program IBM SPSS 25 (9th ed.). Semarang: Badan Penerbit Universitas Diponegoro.

Hadi, A. P., Putri, N. K., \& Faturokhman, A. (2019). Faktor-Faktor Yang Mempengaruhi Penggunaan Informasi Akuntansi Pada Usaha Kecil Dan Menengah. Jurnal Akuntansi Dan Keuangan, 16(2), 165-171.

Hendrawati, E. (2017). Analisis Faktor-Faktor Yang Mempengaruhi Penggunaan Informasi Akuntansi Pada Usaha Mikro, Kecil dan Menengah (UMKM). Jurnal Ilmu Manajemen, 1(2), 43-66.

Hudha, C. (2017). Pengaruh Tingkat Pendidikan, Pengetahuan Akuntansi Dan Pelatihan Akuntansi Terhadap Penggunaan Informasi Akuntansi Dimoderasi Ketidakpastian Lingkungan Usaha Kecil Menengah. Jurnal Ekonomi Pendidikan Dan Kewirausahaan, Vol. 5, pp. 68-90. https://doi.org/10.26740/jepk.v5n1.p68-90

Ikatan Akuntan Indonesia. (2009). Standar Akuntansi Keuangan Entitas Tanpa Akuntabilitas Publik. Jakarta.

Khairunnisa, \& Rustiana, S. (2019). The Effect of Education Level, Business Age and Accounting Knowledge on The Implementation of SME Accounting Information Systems in Industrial Era 4.0 (Empirical Study of MSME in South Tangerang). International Conference on Economics, Management, and Accounting Conference, KnE Social Sciences, 872-887. https://doi.org/10.18502/kss.v3i26.5420

Kieso, D. E., Weygandt, J. J., \& Warfield, T. D. (2018). Akuntansi Keuangan Menengah Edisi IFRS. Jakarta: Salemba Empat.

Kurniawan, M. A., Mahsuni, A. W., \& Hariri. (2020). Analisis Faktor-Faktor Yang Mempengaruhi Penggunaan Informasi Akuntansi Pada Usaha UMKM (Studi Empiris Pada UMKM di Kota Malang). E-Jra, 09(02), 132-145.

Nirwana, A., \& Purnama, D. (2019). Pengaruh Jenjang Pendidikan, Skala Usaha Dan Lama Usaha Terhadap Penggunaan Informasi Akuntansi Pada UMKM Di Kecamatan Ciawigebang. Jurnal Riset Keuangan Dan Akuntansi, 5(4), 55-65. https://doi.org/10.25134/jrka.v5i1.1881

Novianti, D., Mustika, I. W., \& Eka, L. H. (2018). Pengaruh Tingkat Pendidikan, Pelatihan 
Akuntansi, Umur Usaha Dan Skala Usaha Pelaku UMKM Terhadap Penggunaan Informasi Akuntansi Di Kecamatan Purwokerto Utara. Jurnal Ekonomi, Bisnis, Dan Akuntansi (JEBA), 20(3), 1-14.

Prasetyo, W. B. (2020). 2020 Kedai Kopi Diprediksi Tumbuh 15\%. Retrieved December 16, 2020, from Berita Satu website: https://www.beritasatu.com/whisnu-bagusprasetyo/ekonomi/601687/2020-kedai-kopi-diprediksi-tumbuh-15

Priliandani, N. M. I., Pradnyanitasari, P. D., \& Kurniawan, K. A. (2020). Pengaruh Persepsi dan Pengetahuan Akuntansi Pelaku Usaha Mikro Kecil Menengah Terhadap Penggunaan Informasi Akuntansi. Jurnal Akuntansi, Ekonomi Dan Manajemen Bisnis, 8(1), 67-73. https://doi.org/10.32477/jrm.v6i1.29

Rikah. (2018). Perbandingan Faktor Yang Mempengaruhi Penggunaan Informasi Akuntansi Pada Usaha UKM Di Desa Dan Di Kota (Studi Kasus Usaha UKM Kabupaten Rembang). Jurnal Ilmiah Ekonomi, 14(1), 151-169.

Sandi, F. B. (2019). 5 Permasalahan UMKM yang Sering Terjadi di Indonesia dan Solusinya. Retrieved December 16, 2020, from Online-Pajak website: https://www.onlinepajak.com/seputar-pph-final/permasalahan-umkm

Scott, W. R. (2009). Financial Accounting Theory (5th ed.). Toronto Canada: Prentice-Hall.

Sitorus, S. D. H. (2017). Pengaruh Latar Belakang Pendidikan Dan Pengetahuan Tentang Akuntansi Terhadap Penggunaan Sistem Informasi Akuntansi Pada Pedagang Di Wilayah Kelurahan Helvetia Tengah Medan. At-Tawassuth, II(2), 413-436.

Sukriani, L., Dewi, P. E. D. M., \& Wahyuni, M. A. (2018). Pengaruh Tingkat Pendidikan,Pengalaman Kerja, Pelatihan, Dan Penggunaan Teknologi Informasi Terhadap Kualitas Laporan Keuangan Bumdes Di Kecamatan Negara. Jurnal Ilmiah Mahasiswa Akuntansi (JIMAT), 9(3), 85-97.

Tambunan, F. (2019). Pengaruh Pengetahuan Akuntansi Dan Pengalaman Usaha Terhadap Pengembangan Usaha Dan Penggunaan Informasi Akuntansi Sebagai Variabel Intervening (Kajian Empiris Pada Pelaku Usaha Kecil dan Menengah di Kelurahan Tanjung Rejo Kecamatan Medan Sunggal). At:Tawassuth: Jurnal Ekonomi Islam, IV(2), 371-394.

Trisnaningsih, S., \& Haryadi, D. D. (2009). Pendidikan, Pengalaman Dan Independensi Pengaruhnya Terhadap Profesionalisme Auditor (Studi Empiris Pada Kantor Akuntan Publik di Surabaya). Jurnal Strategi Akuntansi, 1(1), 1-18.

Umami, L., Kaukab, M. E., \& Romandhon. (2020). Penggunaan Informasi Akuntansi Pada UMKM Industri Batik. Journal of Economic, Business and Engineering (JEBE), 2(1), 6675.

Undang - Undang Republik Indonesia Nomor 20 Tahun 2008. Tentang Usaha Mikro, Kecil dan Menengah.

Whetyningtyas, A. (2016). Determinan Penggunaan Informasi Akuntansi Pada Usaha Kecil Menengah (UKM). Media Ekonomi Dan Manajemen, 31(2), 88-96.

Yasa, K. S. H., Herawati, N. T., \& Sulindawati, N. L. G. E. (2017). Pengaruh Skala Usaha, Umur Perusahaan, Pengetahuan Akuntansi Terhadap Penggunaan Informasi Akuntansi Pada Usaha Kecil Menengah (Ukm) Di Kecamatan Buleleng Dengan Ketidakpastian Lingkungan Sebagai Variabel Pemoderasi. S1 Ak Universitas Pendidikan Ganesha, 8(2).

Yolanda, N. A., Surya, R. A. S., \& Zarefar, A. (2020). Faktor-Faktor Yang Mempengaruhi 
Penggunaan Informasi Akuntansi Pada UMKM Dengan Ketidakpastian Lingkungan Sebagai Variabel Moderasi (Studi Empiris Pada UMKM Di Kabupaten Kuantan Singingi). Jurnal Politeknik Caltex Riau, 13(1), 21-30.

Zulkarnnaeni, A. S., \& Rizki, N. C. (2019). Pengaruh Pendidikan Terakhir, Skala Usaha Dan Pelatihan Akuntansi Terhadap Penggunaan Informasi Akuntansi Pada UKM (Studi Empiris Terhadap UKM Di Desa Kedensari, Kecamatan Tanggulangin Kabupaten Sidoarjo). JIAI (Jurnal Ilmiah Akuntansi Indonesia), 4(2), 166-174. https://doi.org/10.32528/jiai.v4i2.2662 